\title{
The Effects of Globalization and the Sharing Economy on the Intercultural Communication of the Young Generation
}

\author{
Aleš Hes ${ }^{1, *}$, Martina Švecová ${ }^{1}$ \\ ${ }^{1}$ University of Finance and Administration in Prague, Estonska 500, CZ 101 00, Prague 10, Czech \\ Republic
}

\begin{abstract}
.
Research background: The pros of globalization processes are a challenge for society, but also a warning not to turn to society itself. E.g. disproportionate support of consumption and consumerist lifestyle can totally destroy the social belonging of individual cultures and the environment. With the growing globalization processes of the world's population, communication is an important means of the stability of postmodern society. It can establish and eliminate the causes of communication noise, which can grow into a conflict. All this has an impact on the global movement of people and intercultural communication, especially among the younger generation.

Purpose of the article: The article points to the need to create a unified and fair communication platform for the young generation to properly understand their position and position in the intercultural environment and not to be manipulated by global communication, which is managed by multinational companies.

Methods: The main methods to be used will be structured analysis and simple description of facts, as well as methods of synthesis, logical and deductive procedures in order to identify and formulate the effects of globalization on the formation of relations of the young generation.

Findings \& Value added: The article will present both a description of the current behavior of the young generation in the context of their possibilities of intercultural communication and a recommendation that information and knowledge become a source of economic growth.
\end{abstract}

Keywords: globalization; shared economy; behavior; communication; generation $Y$

JEL Classification: $A 13 ;$ F6; M31; O15; O19

* Corresponding author: ales.hes@mail.vsfs.cz 


\section{Introduction}

Globalization (a world without borders) has a very important relation to consumer society and changes in a group of influential economic players such as China, Brazil and India. These players will become much stricter opponents of the current leading economies - the US and the EU. For example, in normal times China's influence in the equity market has risen to a level close to that of the United States, although the relative impact of the United States became stronger in crisis periods. Nonetheless, China's bond market remains a negligible player. China's role may be interpreted as a "regional pull" factor, while that of the United States remains a key "global push" factor [1].

The global movement of people has led to the fact that individual states have become multicultural societies consisting of members of different cultures. Contacts are constantly developing within the framework of international cooperation, which has contributed to the unceasing geographic growth in the labour market. It is therefore necessary to prepare this human capital not only from a specialist and linguistic point of view, but also from the point of view of the specific cultural characteristics of the individual nations. This involves preparation for life in a multicultural reality and preparation for the social, political and economic aspects of interaction between people within the framework of a different cultural environment. [2]

Differences in the cultural background and value structure of different ethnic groups pose significant risks of confrontation, which can be stimulated through global means of communication. However, it is desirable throughout society for different cultures to get to know each other and create coherent and compromise relationships. That is why global communication must create a peaceful environment, be a means of bringing together and recognizing different cultures, and not encourage incitement and hostility. For example, in the late 1990s, protests emerged against the effects of globalization, which were linked to rising unemployment due to relocations to lower labour costs and unequal subsidies for the production of certain products that were sold at dumped prices. $[3,4]$

Politically, these processes were hidden under the so-called liberalization of international trade. Although countries are aware of the dangers (e.g., the loss of their own economic identity in certain sectors), global processes continue, with people being served as positives rather than negatives. So the debate about globalization does not stop and many authors have different views on this matter. Some authors [5,6] focused on the relationship between the state and the globalizing market and talked about the arrival of a qualitatively new situation - a global economy whose forces are undermining the position of the state. On the other hand, sceptics [7] have argued that the position of the state has not changed and that there can be no question of a homogeneous global market [8]. No matter how the discussions are conducted, it is clear that this issue is crucial for the human population and it is necessary to constantly study and analyse it from different perspectives.

From the point of view of intercultural communication, the topic of globalization is very topical in connection with the progressive enlargement of the European Union and the current ever stronger migratory movements. According to Welsch [9], the concept of interculturality is based on the traditional idea that cultures are a kind of islands, strictly limited and separate entities that can ignore, underestimate, fight against each other or try to understand each other, exchange values, models, ways of acting and living. The dependence between globalization and intercultural communication is the subject of research by many scholars [10-15]. 


\section{Material and methodology}

The main methods used in the elaboration of this topic were structured analysis and description of facts, as well as methods of synthesis, logical and deductive procedures to identify the effects of global communication and shared economy on shaping the attitudes of young people influencing their opinion structure in post-modern society. The topic is organized according to the logic of facts and the deduction of results from the analysis of professional scientific texts into a complex meaning, which identifies the basic impacts of current communication in the global environment on the lifestyle of the young generation.

\section{Results and discussion}

The Internet and new digital media are a key environment for communication in today's post-modern society. Almost no industry can do without them, they have become part of our lifestyle and expression. However, their influence on the mental sphere of people is alarming. In the field of neurobiology, the use of smart media is reflected in certain changes in people's behaviour and thinking. Perception, thinking, experiencing, feeling and acting leave memory traces in the brain, which can be photographed or filmed today. These synapses with electrical signals between nerve cells have begun to change since the turn of the millennium (when they were first imaged). The human brain develops through constant learning. However, the time spent with digital media is a stagnant period for the brain. Over a long period of evolution, the brain has been constantly adapting to something, giving rise to diseases of civilization that are more common today. The mental and mental spheres of society are determined and begin to manifest themselves in different mechanisms and processes that affect a person's cognitive performance, such as attention, speech development or intelligence. It is certain that the media significantly influence emotional and socio-psychological processes, including moral ethical attitudes and personal identity. This phenomenon is even referred to as digital dementia. Digital dementia is created by the uneven development of the brain. The current young generation is not learning, but is working with information that has already been created, which may not even be verified and true. Perception is narrowed down to information and passed on without becoming stuck in memory. [16]

\subsection{Generace Z a média}

Generation $\mathrm{Z}$ is a very interesting generation. It's not just that it's a generation of Digital Natives. It is also very important for the definition to realize that this is the last whole generation, brought up by digital immigrants and at the same time the first generation of interactive media. It lives on the border between online and offline, at a time when the online world is just evolving. Meyrowitz [17] already points mainly to television, but both television and digital media are changing social reality. Previously, parents had the opportunity to check the contents that children read in books. At present, children already have the opportunity to find content on the Internet that would not be considered appropriate in the era of the printed word. Growing up in an environment where, according to my previous research, parents of young children (up to 6 years of age) approach media education passively, control the time spent watching AV content and also the content of what children watch, but do not use active media education in preparation work with the media. [18] Digital content thus comes as an "uninvited guest" to her homes, to a place that is considered safe. Volek [19] describes it as the place where our emotional experiences are strongest, to the basic formation: I, that's how it happens in the space of home. 
Both authors point to the clear effects of the media on children and young people. From a global perspective, Generation $\mathrm{Z}$ can be characterized by the mainstream culture of most countries in Europe, the United States, especially the large cities of these countries. Their strong economic environment creates conditions for higher product production and higher consumption by customers. People no longer buy just what they need to survive, but what they enjoy, what brings them pleasure and happiness. This is how most of society and the $\mathrm{Z}$ generation behave. It can simply be stated that the media significantly support the development of marketing and communication skills and the development of "consumerism". The young generation develops their model of behaviour, which can be characterized as "methodological collectivism". It is an individual who pursues his own benefit, however, his actions are influenced by the opinions and values of the environment. In essence, this means that the behaviour of an individual is not independent and is influenced by the environment in the form of various regulators, styles, sanctions. [20]

Generation $\mathrm{Z}$ is the first generation to be surrounded by interactive media and growing up in a Web 2.0 environment. It is also referred to as iGeneration. While their parents had various devices for watching television, playing video games, playing music, making phone calls, and so on, this generation does all of these tasks on a single device that fits in its pocket. This high-tech era helps them to be powerful both online and offline. Generation $\mathrm{Z}$ lives in both virtual and physical reality, has easy access to world events. He sees the world's problems; he wants to find a solution. [21] Our new electric selves in the digital age go beyond the old boundaries of human experience, people have become electrified: "Humans become electric", new disciplines are emerging, such as cyber psychology that explains human behaviour in cyberspace "), in which the term" digital psyche "is used what is human within the digital world. Suler points out that thanks to the digital world, people are able to manifest, discover their inner characteristics. And he adds that as we better understand the possibilities of cyberspace, we realize that a healthy individual is able to integrate offline and online life. But for now, we do not yet know this world well enough and we must realize that we are in the same situation as before the birth of the universe. [22]

It is clear that Generation $\mathrm{Z}$ is affected by strong global media pressure, which is caused by new information technologies and especially social networks, which are becoming more and more accessible to everyone. (Table 1, Table 2)

Table 1. Internet usage statistics by world region

\begin{tabular}{|l|r|r|r|r|r|}
\hline \multicolumn{7}{|c|}{ World Internet usage and world population statistics / 2019/ } \\
\hline Region & $\begin{array}{c}\text { Population in } \\
2019\end{array}$ & $\begin{array}{c}\text { \% of } \\
\text { world } \\
\text { population }\end{array}$ & $\begin{array}{c}\text { Internet users } \\
(30 / 06 / 2019)\end{array}$ & $\begin{array}{c}\text { Proportion of } \\
\text { population from } \\
\text { population in \% }\end{array}$ & $\begin{array}{c}\text { Share of } \\
\text { world } \\
\text { users in } \\
\%\end{array}$ \\
\hline Africa & 1320038716 & 17.1 & 522809480 & 39.6 & 11.5 \\
\hline Asia & 4241972790 & 55.0 & 2300469859 & 54.2 & 50.7 \\
\hline Europe & 829173007 & 10.7 & 727559682 & 87.7 & 16.0 \\
\hline $\begin{array}{l}\text { Latin America- } \\
\text { Caribbean, }\end{array}$ & 658345826 & 8.5 & 453702292 & 68.9 & 10.0 \\
\hline Middle East & 258356867 & 3.3 & 175502589 & 67.9 & 3.9 \\
\hline North America & 366496802 & 4.7 & 327568628 & 89.4 & 7.2 \\
\hline Australia/Oceania & 41839201 & 0.5 & 28636278 & 68.4 & 0.6 \\
\hline Total & 7716223209 & 100.0 & 4536248808 & 58.8 & 100. \\
\hline
\end{tabular}

Source: World Internet Users and 2019 Population Stats. In: Internet World Stats [online]. India:

Miniwatts, 2019 [cit. 2019-09-19]. <https://www.internetworldstats.com/stats.htm>. 
Table 2. Internet and social networks

\begin{tabular}{|l|l|l|l|}
\hline Statistics globally & Year & Number & Information source \\
\hline $\begin{array}{l}\text { Number of internet } \\
\text { users worldwide }\end{array}$ & $01 / 2019$ & $4,388 \mathrm{mld}$. & $\begin{array}{l}\text { https:/www.smartinsights.com/social-media- } \\
\text { marketing/social-media-strategy/new-global-social- } \\
\text { media-research/ }\end{array}$ \\
\hline $\begin{array}{l}\text { Number of social } \\
\text { media users }\end{array}$ & $01 / 2019$ & $3,484 \mathrm{mld}$. & $\begin{array}{l}\text { https:/www.smartinsights.com/social-media- } \\
\text { marketing/social-media-strategy/new-global-social- } \\
\text { media-research/ }\end{array}$ \\
\hline $\begin{array}{l}\text { Number of mobile } \\
\text { phone users }\end{array}$ & 2019 & $5,112 \mathrm{mld}$. & $\begin{array}{l}\text { https:/www.smartinsights.com/social-media- } \\
\text { marketing/social-media-strategy/new-global-social- } \\
\text { media-research/ }\end{array}$ \\
\hline $\begin{array}{l}\text { Number of } \\
\text { Facebook users }\end{array}$ & 2018 & $\begin{array}{l}\text { Total 2,32 mld. } \\
\text { Daily } \\
1,3 \mathrm{mld} .\end{array}$ & $\begin{array}{l}\text { https:/www.mediaguru.cz/clanky/2019/01/faceboo } \\
\text { k-na-konci-roku-zastavil-pokles-uzivatelu/ }\end{array}$ \\
\hline
\end{tabular}

Source: own processing

For a comparison with the world, the use of social networks of $\mathrm{Z}$ generations in the Czech Republic is shown in Table 3.

Table 3 Use of social networks by young people aged 15-29, Czech Republic

\begin{tabular}{|l|l|}
\hline Category & Data \\
\hline Social Networks & Visits $93 \%$ daily, contributes $17 \%$ daily, does not contribute $12 \%$ at al \\
\hline Facebook & Repeatedly visits $94 \%$ \\
\hline Instagram & Repeatedly visits $68 \%$ \\
\hline $\begin{array}{l}\text { Year-on-year } \\
\text { increase / decrease }\end{array}$ & $\begin{array}{l}\text { Instagram }+6 \%, \text { Instagram Stories }+29 \% \text { (new), LinkedIn }+2 \% \text {, Twitter - } \\
1 \% \text {, Facebook }-2 \% \text {, YouTube }-2 \%\end{array}$ \\
\hline Network Usage for & Entertainment $67 \%$, Information $49 \%$ \\
\hline $\begin{array}{l}\text { Chat applications } \\
\text { Very often }\end{array}$ & $\begin{array}{l}\text { Messenger } 87 \%, \text { WhatsApp } 25 \%, \text { Viber all ages } 7 \% \\
\text { Snapchat all ages } 2 \%\end{array}$ \\
\hline
\end{tabular}

Source: own processing by Ami Digital Index 2019. In: AMI Digital [online]. 2019 [2019-09-19].

$<$ http://index.amidigital.cz/wp-content/uploads/2019/06/AMI_Digital_Index_2019_Summary.pdf $>$.

Generation $\mathrm{Z}$ lives in a visual culture. At a time when the Internet is the most important source of information, change rules without a fixed order. The vast majority of this generation is connected to the Internet and also has it on their mobile phones. But because digitization in the Czech Republic is still evolving, this generation is forced to communicate face-to-face and use "old approaches", especially as far as authorities, health care and education are concerned. It is thus on the border of two worlds, one online - more advanced and the other offline. Of course, they are trying to take advantage of a simpler online path, which is why this $\mathrm{Z}$ generation often seems lazy. The total use of the current digital world according to the DESI Index has the entire EU28 reserves, even though the young generation of the Czech Republic, according to statistics, is above the EU28 average.

This means that although the Czech Republic is generally lagging behind developed Europe, it will soon become relevant with this generation. Experience from US research (Goldman Sachs Global Investment Research, 2015) shows that lower income and higher debt of Generation Y are changing its approach to ownership, and Generation Z is gradually focusing on renting and buying goods as services. These are mainly music, luxury goods and cars. American economist Jeremy Rifkin claims that by a quarter of a century, car sharing will be the norm, while his individual ownership will be anomaly.

Generation Y avoids stereotypes, as evidenced by the massive growth of its interest in a better health lifestyle and higher spending on sportswear. On the contrary, Generation Z is looking for non-standard paths that are not burdened by the effort of administrative tasks and personal contact. This can be interpreted as meaning that the shared economy will be more acceptable for generation $\mathrm{Z}$ than for generation $\mathrm{Y}$. 


\subsection{Generation $Z$ and sharing economy}

Sharing economy is a common consumption based on the mutual exchange of objects, which is provided by its owner for use to those who do not pay to buy an object for various reasons. Most of these reasons include the low level of its use or the financial situation. Family lending has become the model of a sharing economy, the difference being that foreign people borrow items from each other. In addition to objects (car, real estate), the provision of services (e.g. the offer of one-off job offers) is also included in the sharing economy. Today, multinational corporations are behind a sharing economy and have become a strong competitor in many sectors. The subjects of business in a sharing economy can be divided into five areas:

1. Travel.

2. Shared transport.

3. Finance.

4. Employees.

5. Streaming services and videos. [23]

In the Czech Republic, the sharing economy has established itself more slowly than in the surrounding developed European countries (e.g. Italy, Spain, Great Britain). In 2017, only $7-8 \%$ of the population of the Czech Republic used shared services, currently it is around $10-15 \%$. The process of sharing economy is based on information technology, where specific shared services are recommended using applications. It is an interesting form of interactive communication, which is based on trust and references of a shared subject. Generation $\mathrm{Z}$ can use the sharing economy much better thanks to its popularity to search for information in the online environment - in applications.

For Generation $\mathrm{Z}$ a sharing economy is a beneficial economic phenomenon based on making new contacts without meeting in person. The trust placed in the shared service is the basis for the self-regulation of the subject of business provided and leads the $\mathrm{Z}$ generation to economic independence and literacy. However, the shared economy also has disadvantages. One of the most serious disadvantages is that shared service providers often do not use legal protections as in traditional business relationships, and in the event of a breach of the rules, the injured party does not have sufficient legal basis to recover damages. Nevertheless, the sharing economy is estimated by Deloitte to generate around two miliard crowns in the Czech Republic. The sharing economy in the Czech Republic is facing certain regulatory changes, supporting the precise definition of providers of shared objects and the objects of business themselves. This is a decision:

- which service fulfils the characteristics of a business or has the character of permitted or prohibited activities,

- which will make partial changes to the legal environment in defining more precise guidelines between entrepreneurship and other gainful activity,

- which comprehensively solves extra income in a sharing economy.

It follows that the shared economy will develop as a new economic and business trend.

For Generation $\mathrm{Z}$ this is a great challenge and opportunity to combine its focus on information technology with business or the use of shared objects. The reason for this statement is that Generation $\mathrm{Z}$ avoids face-to-face communication and communicates primarily through online chatting. It seeks out information and communicates with new people through social networks and applications, which is a beneficial factor for the sharing economy, given that the vast majority of the offer of shared items is kept in applications. They also avoid public transport and look for alternative services. [24,25] 


\section{Conclusion}

Analysis of the communication behaviour of the $\mathrm{Z}$ generation has shown that it is the result and part of the effects of globalization. It is influenced by strong global media pressure, which is caused by new information technologies and especially social networks, which are becoming more and more accessible to everyone. Her communication activity is manifested mainly in the Internet environment and lives in a visual culture. It is the first generation that is surrounded by interactive media and grows in a Web 2.0 environment and is referred to as iGeneration. The high-tech era helps them to be powerful both online and offline. Generation $\mathrm{Z}$ lives in both virtual and physical reality, has easy access to world events. This adds to the development of a sharing economy that makes full use of global information technology. Through applications, it easily gets into the field of view of young generations $\mathrm{Y}$ and $\mathrm{Z}$. There is a realistic assumption that generation $\mathrm{Z}$ in particular will make more use of the offers of a sharing economy, as ownership of objects will not be a priority for them. For Generation Z, the immediate fulfilment of its needs will be dominant, and this is a great potential for a sharing economy.

This paper is an output of the science project student's specific research No. 7427/2019/07 University of Finance and Administration Prague under the title Model of intercultural tolerance at selected universities

\section{References}

1. Shu, C., He, D., Dong, JY., Wang, HL. (2018). Regional pull vs global push factors: China and US influence on Asian financial markets. Journal of International Money and Finance, 87, 112-132.

2. Alexy, J. (2006). Progresívne smery manažmentu vo virtuálnom prostredí. Research papers, 2(2), 7-10.

3. Stiglitz, D. (2006). Making globalization work. London: Pinguin Group.

4. Balcerzak, A.P. (2020). Quality of institutions in the European Union countries. Application of Topsis based on entropy measure $\mathrm{F}$ or objective weighting. Acta Polytechnica Hungarica, 17(1), 101-122.

5. Janoskova, K., Kliestikova, J. (2018). Analysis of the impact of selected determinants on brand value. Journal of International Studies, 11(1), 152-162.

6. Langley, P. (2000). Confronting Globalization: International Political Economy and Its Critics. Millennium: Journal of International Studies, 29(2), 461-469.

7. Wade, R. (1996). Globalization and its Limits: Reports of the Death of the National Economy Are Greatly Exaggerated. National diversity and global capitalism. Ithaca: Cornell university Press.

8. Císař, O. (2003). Vzniká globální občanská společnost? Nestátní aktéři ve světové politice. Mezinárodní vztahy, 4, 5-23.

9. Welsch, W. (1995). Transkulturalität. Zur veränderten Verfassheit heutigen Kulturen. Zeitschrift für Kulturaustausch, 45(1), 40-48.

10. Boldea, I. (2014). Globalization and Intercultural Communication. In I. Boldea (Eds.), Globalization and Intercultural Dialaogue: Multidisciplinary Perspectives Communication and Public Relations (pp. 7-18). Mures: Arhipelag WWI Press. 
11. Akova, S., Kantar, G. (2020). Globalization in the context of multiculturalism and ethnicity in the Western Balkans and intercultural communication. Journal of Public Affairs, early access.

12. Rey, J., Caro, FJ., Balhadj, S. (2017). The Challenges of Intercultural Communication in the Age of Globalization: The Case of Spanish Companies Based in Morocco. Prisma Social, 17, 415-437.

13. Van Praet, E. (2016). Intercultural communication. Globalization and social justice. Communications - European Journal of Communication Research, 4(3), 367-369.

14. Ten, Y. P. (2014). Symbol as Universal Non-Verbal Means of Intercultural Communication in the Time of Globalization. Journal of Teaching English for Specific and Academic Purposes, 2(1), 33-43.

15. Zotzmann, K. (2007). Globalization and Intercultural Communication. Cultura Lenguaje Y Representacion - Revista de Estudios Culturales de La Universitat Jaume, 4, 253-268.

16. Spitzer, M. (2012). Digital Demenz: Wie wir uns und unsere Kinder um den Verstand bringen. Munchen: Droemersche Verlagsanstalt Th. Knaur Nacht.

17. Meyrowitz, J. (2006). Všude a nikde: vliv elektronických médií na sociální chování. Praha: Karolinum.

18. Švecová, M. (2016). Večerníček a do postele! Regulácia užívania televízie vo výchove diet'at'a do šiestich rokov. [Rigorózní práce] Praha: Univerzita Karlova v Praze, Fakulta sociálních věd.

19. Volek, J. (1999). Televize jako spolutvůrce domova a extenze rodiny. Sociální studia, $4,17-41$.

20. Prudký, L. et al. (2009). Studie o hodnotách, Plzeň: Aleš Čeněk.

21. Mirzoeff, N. (2018). Jak vidět svět. Praha: ArtMap.

22. Suler, J. (2019). Psychology of the Digital Age: Humans become electric. New York: Cambridge University Press.

23. Ducci, F. (2018). Competition Law and Policy Issues in the Sharing Economy. Law and the "Sharing Economy": Regulating Online Market Platforms (pp. 295-318). Ottawa: University of Ottawa Press.

24. Polianskaya, A. (2018, January 28). Millenials shun face-to-face-conversations in favour of social media and online messaging. Retrieved from: https://www.independent.co.uk/news/health/millennials-social-media-cancer-researchuk-study-a8182211.html

25. Kliestik, T., Valaskova, K., Lazaroiu, G., Kovacova, M., Vrbka, J. (2020). Remaining financially healthy and competitive: The role of financial predictors. Journal of Competitiveness, 12(1), 74-92. 